\title{
RESETTABLE FUSES FOR OVERCURRENT PROTECTION IN PHOTOVOLTAIC SOLAR ARRAY SYSTEMS
}

\author{
A.Yu. Lyashkov*, A.S. Tonkoshkur, S.F. Lyagushyn \\ Oles Honchar Dnipro National University, Dnipro, Ukraine \\ e-mail:alexdnu@ukr.net
}

\begin{abstract}
The general scheme of using self-repairing PolySwitch-type fuses to limit the current in photovoltaic systems of solar arrays and the resulting requirements for their parameters are analyzed. The possibilities of applying modern serial resettable fuses for solving the problem of increasing the reliability of solar panels are studied. In particular, it is established that currently available nomenclature of fuses of the PolySwitch type allows implementing protection of photovoltaic systems of solar arrays against current overloads at the level of photovoltaic modules. At the same time, for the implementation of such protection at the level of solar cells, it is necessary to develop fuses with lower values of electrical resistance in the conducting state and lower tripping currents.

Keywords: PolySwitch, resettable fuses, photovoltaic cell, solar array, protection against overloads.
\end{abstract}

Received 11.11.2018; Received in revised form 10.12.2018; Accepted 21.12.2018

\section{Introduction}

Current overloads are one of the most serious sources of unreliability of photovoltaic systems of solar arrays [1-3]. Their physical causes can be damage in the course of operation of their constituent elements, "hidden" manufacturing defects, faulty blocking and bypass diodes, the results of insulation degradation under the environment action and effects of space and other solid particles of natural and artificial origin $[4,5]$.

The most adverse consequences of the occurrence of current overloads caused by short circuits take place in parallel connections of photovoltaic cells (PVC) and their modules (PVM). In this case, they lead to the failure of the entire connection and the occurrence of substantial overheating due to the summation of the currents of individual elements. As a result, this can cause abnormal (fire hazardous) situations.

Currently, considerable attention is paid to the development of methods and means for preventing the occurrence of local overheating ("hot spots") in photovoltaic components of solar arrays. However, such means are not universal. The use of a PVC with a low reversebreakdown voltage limits the power dissipated during heating of its local areas, but can be an effective way to prevent a "hot spot" if the amount of dissipated power is insufficient to damage the PVC [6].

The available simulation results and experimental data indicate that bypass diodes in subpanel lines of photovoltaic cells used for these purposes do not fully protect against the appearance of "hot spots" [3, 7-9].

Bypass diodes are more effective for preventing "hot spots" at very short PVC line lengths that are not used in modern panel design for economic reasons. Active bypass switches, as well as technical means based on the detection of "hot spots", are an improvement over the bypass diode, but they require more complex circuit solutions and expenses $[10,11]$.

Recently, overload protection with using elements of functional electronics has been considered as one of the promising directions for solving the problem under consideration. In particular, it is proposed to isolate inactive (shaded or defective) areas of both individual photovoltaic cells and their modules through applying relatively new and widely used resettable fuses (RF) of the PolySwitch type [3, 12]. Such elements of electrical and thermal protection have already found application in batteries and galvanic power sources [13-15].

The present paper is devoted to measuring and analyzing the parameters of industrial self-resetting fuses for solar panel systems. The purpose of the work is to analyze the general 
scheme of using self-repairing Polyswitch fuses to limit the current in photovoltaic systems of solar arrays and the resulting requirements for their parameters. The paper identifies the possibilities of the modern commercial base of such functional electronic devices for solving the problem of increasing the reliability of solar arrays.

\section{General scheme of RF use to limit the current in parallel connections of photovoltaic components}

As already mentioned, short circuits are most undesirable in parallel connections both photovoltaic cells and their modules (PVC series connections).

In Fig. 1 a scheme of applying an RF to limit the current in the unit (i.e. parallel connection) of PVM's is shown. In a similar scheme for the parallel connection of PVC's, the only PVC should be left instead of the serial connections of PVC's.

A short circuit of one module $P V_{n}$ in the absence of an RF leads to the loss of the entire parallel circuit containing other serviceable components (Fig. 1). The presence of resettable fuses $F u_{i}$, connected in series with each photogenerating component $P V_{i}$, makes it possible to preserve and operate the serviceable PVM's in the presence of a short circuit in one of them.

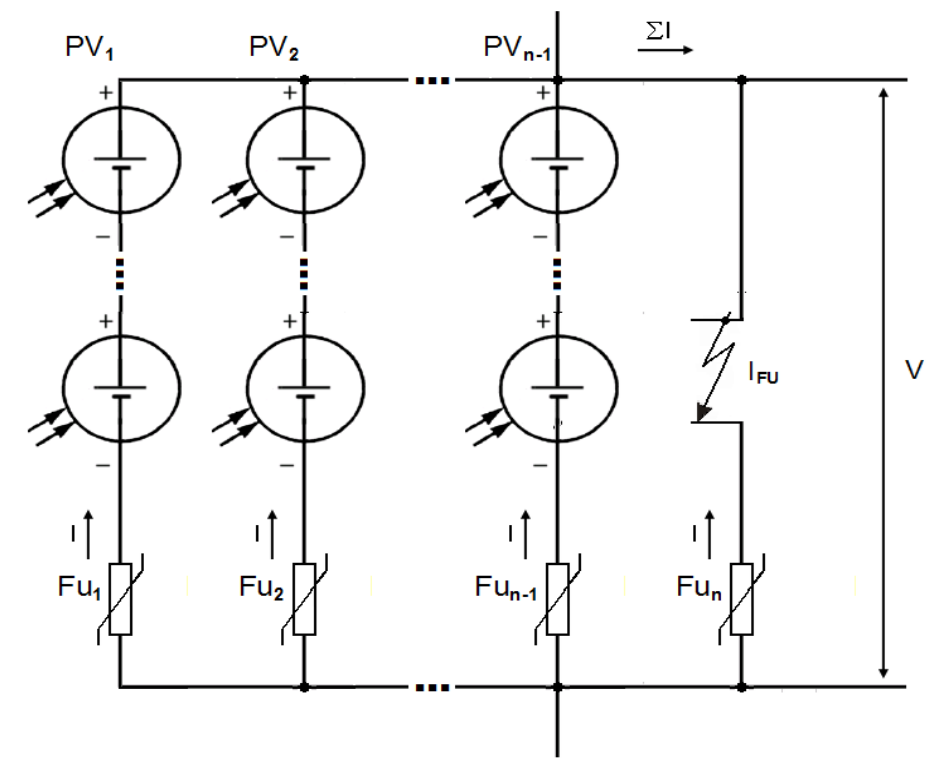

Fig. 1. A simplified scheme illustrating short-circuit protection in parallel connection of photovoltaic modules $P V_{i}(i=1,2, \ldots n-1)$ with using resettable fuses $F u_{i}(i=1,2, \ldots n)$.

$I_{F U}$ and $V$ are the current and voltage of a short-circuited parallel connection of the PVM component; $I$ and $V$ are currents generated by the photovoltaic module $P V_{i}$.

\section{Peculiarities of applying resettable fuses in photovoltaic systems}

\subsection{Equivalent photovoltaic cell scheme}

PVC's have non-linear current-voltage characteristics, which depend on the level of solar radiation, ambient temperature, and features of the cell itself. Currently, there are several basic substitution schemes for PVC, whose mathematical description is used in modern simulation [16-18].

The most well-known of them contains a photocurrent source $\left(i_{p h} \approx i_{s c}\right.$, where $i_{s c}$ is the short-circuit current of the PVC) and a parallel-connected diode $(D)$ simulating a p-n junction, shunt resistor $\left(r_{s h}\right)$ simulating leakage currents, and series resistor $\left(r_{s}\right)$, which characterizes internal resistance of the cell and contacts). In the operating mode of the PVC 
(direct-shifted photodiode) the leakage current $\left(i_{0}\right)$ is neglected, i.e. it is assumed that $r_{s h}$ tends to infinity and the equivalent substitution scheme of the PVC has the form shown in Fig. 2.

To describe the photoelectric properties of PVM similar circuit elements are used: the short circuit current of the photovoltaic module $\left(I_{s c}\right)$, the equivalent series resistance of the module $\left(r_{s}\right)$, and others [16].

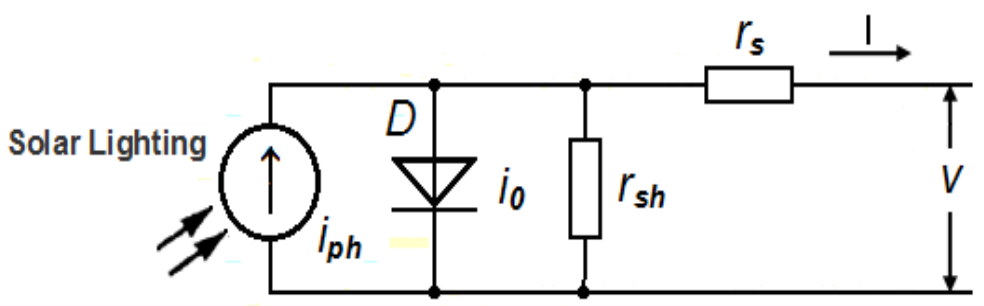

Fig. 2. Simplified equivalent substitution scheme for PVC.

\subsection{Requirements for resettable fuse parameters}

PolySwitch resettable fuses have a temperature dependence of resistance $R_{F u}$ that increases with increasing temperature; the dependence has three characteristic sections. At relatively small temperatures (section 1) there is a gradual increase in the fuse resistance against temperature. In a narrow temperature range at about $125^{\circ} \mathrm{C}$, a sharp increase (by several orders of magnitude) in the resistance of the RF's is observed (section 2). With a further increase in temperature, their resistance dependence on temperature also has a smooth character (section 3).

The physical mechanism of the cause of such a jump-like dependence is determined by the structural features of the main functional material of the RF, which is a nanocomposite with a non-conductive polymer matrix and highly conductive nanocarbon filler. Due to carbon channels in the cold state (section 1), the nanocomposite is a conductor with low intrinsic resistance. When heated above a certain temperature (transition temperature), carbon channels are broken due to the volume expansion of the polymer matrix and/or transformation of the crystal structure of the matrix into amorphous and electrical resistance of the nanocomposite increases drastically (section 2) [13, 19]. At the high-temperature section 3 , the structure of the conductive channels is completely destroyed and the resistance of the RF reaches its maximum value.

The technical application belongs to sections 1 (high conducting state) and 2 (abrupt transition to the low conducting state). As the main parameters important for their use in the scheme of Fig. 1 the following values should be taken

- RF resistance in the conducting state (determined by passport values $R_{\min }$ - minimum initial resistance or $R_{1 \max }$ - maximum resistance after one hour of recovery at a given ambient temperature).

- tripping current $I_{\text {trip }}$, i.e. minimum current through the RF, at which the transition from its conducting state to the non-conducting one occurs.

Protection of parallel connection of photovoltaic components of solar arrays can be implemented under the conditions

$$
R_{\min }\left(\text { or } R_{1 \max }\right)<<R_{s},
$$

that is, the presence of such fuses in the electrical circuit should not affect the normal operation of the PVM, and

$$
(n-1) I>I_{\text {trip }}>I_{s c},
$$


i.e., the tripping current of the RF must be greater than the short circuit current of the PVC $I_{s c}$ and less than the current in the parallel connection of the PV's in the operating mode $(n-1) I$, where $(n-1)$ is the number of healthy photovoltaic modules (Fig. 1).

\section{Electrical characteristics of commercial resettable fuses with low tripping currents}

The main functional characteristics of RF's are the current-voltage characteristic (CVC) and the temperature dependence of the resistance. For the analysis of these characteristics, a number of industrial RF's of various manufacturers were selected (Table 1), which most closely correspond in the resistance $R_{\min }$ (or $R_{1 \max }$ ) ranges and the tripping current $I_{\text {trip }}$ to the conditions of their applicability in photovoltaic systems of real solar arrays. These conditions can be formulated as the requirement of low resistance in the conducting state (1) and a small tripping current (2).

The nomenclature and parameters of the investigated RF samples

Table 1

\begin{tabular}{|l|l|l|l|}
\hline Sample No. & \multicolumn{1}{|c|}{ Resettable fuse } & \multicolumn{1}{c|}{$R_{\min }, \mathrm{Ohm}$} & \multicolumn{1}{c|}{$I_{\text {trip }}, \mathrm{A}$} \\
\hline 1 & RXE160 & 0,09 & 3,2 \\
\hline 2 & FRH150-600F & 6 & 0,3 \\
\hline 3 & FRX050-60F & 0,5 & 1 \\
\hline 4 & MF-R110 & 0,10 & 2,2 \\
\hline 5 & TRF250-145-2 & 14 & 0,29 \\
\hline 6 & FRH120-250UF & 6 & 0,24 \\
\hline 7 & 1206 L012 & 1,5 & 0,29 \\
\hline
\end{tabular}

When measuring the temperature dependences of resistance, the samples were placed in a heating chamber and a digital multimeter was connected to them. The rate of temperature rise, controlled with a mercury thermometer, was $40^{\circ} \mathrm{C} / \mathrm{h}$. The experimental temperature dependences of resistance (Fig. 3) fully correspond to the description given in paragraph 2.2.

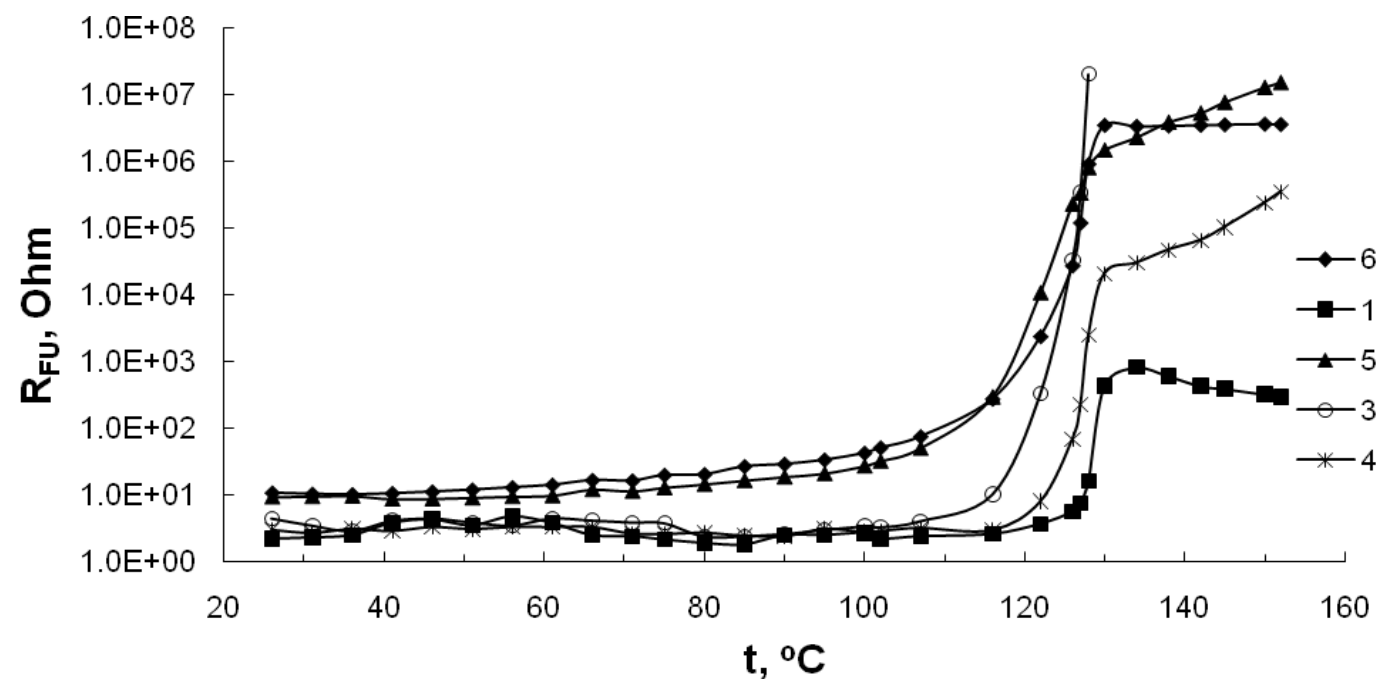

Fig. 3. Temperature dependences of electrical resistance $R_{F u}$ of low-power typical $R F$. The curves correspond to RF's, the parameters of which are given in Table 1. 
The current-voltage characteristics of the investigated samples of RF are presented in Fig. 4 and look like similar characteristics for posistors [21]. With increasing voltage, the current initially increases, this section corresponds to section 1 of the temperature dependences of the resistance (see paragraph 2.2 and Fig. 3). A further increase in voltage leads to a Joule heating of the composite and a sharp increase in resistance due to melting of the crystalline phase of the polymer (section 2), and the current through the RF drops drastically. If we continue to increase the voltage on the sample, this leads to a relatively smooth decrease or stabilization of the current (section 3).

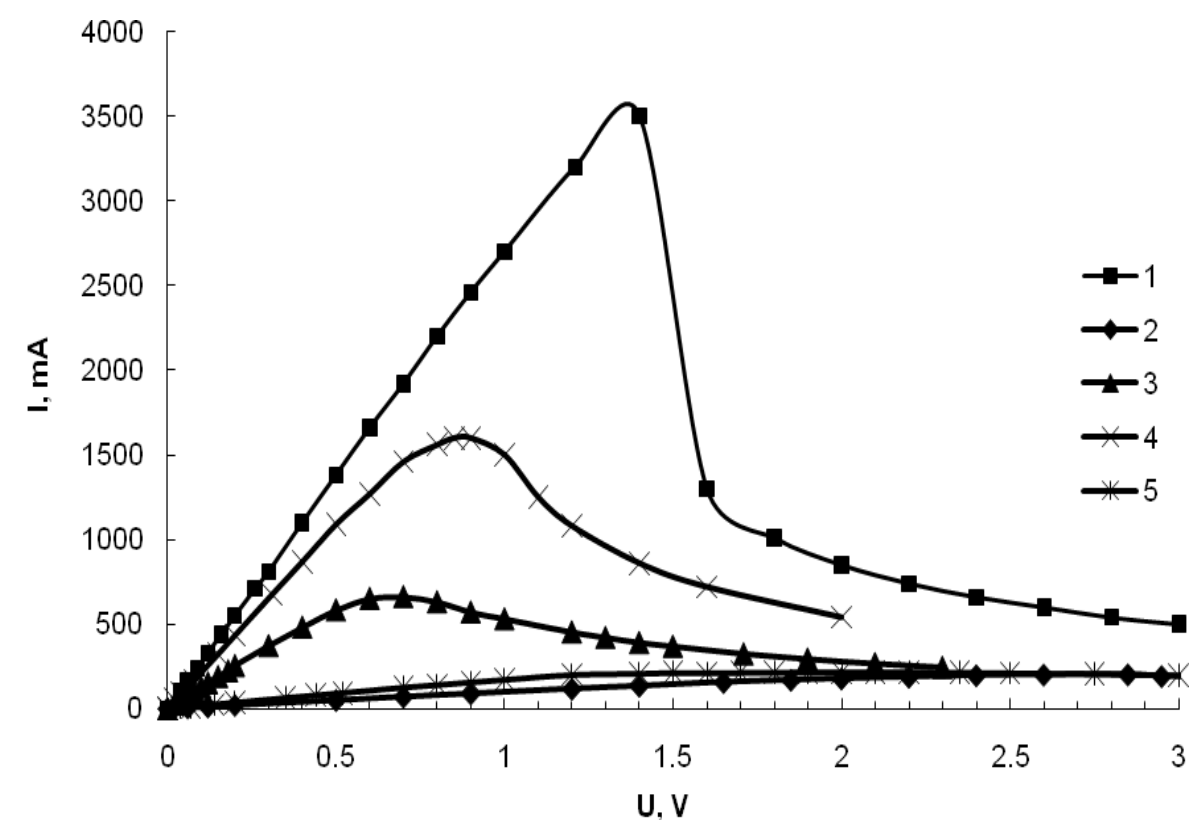

Fig. 4. Current-voltage characteristics $I_{F u}(U)$ of the low-power typical RF's. The curves correspond to the RF's, the parameters of which are given in Table 1.

\section{Correlation between resistance in conductive state and tripping current}

In accordance with conditions (1) and (2), to determine the suitability of a specific RF as an element of protection against current overloads the key parameters are $I_{\text {trip }}$ and $R_{\min }$ that are not independent. $R_{\min }$ determines the dissipated power, and $I_{\text {trip }}$ is determined by its specific value, which provides heating of the RF material to the tripping temperature.

Fig. 5 presents the correlation dependence, its coordinates correspond to the values of $I_{\text {trip }}$ and $R_{\min }$ parameters for RF's commercially produced by companies Bourns, Inc. [22] and Littelfuse, Inc. [23].

As can be seen, the correlation dependence shows a tendency to $I_{\text {trip }}$ decrease with $R_{\min }$ growth. The determination coefficients of dependencies are $\mathrm{R}^{2}=0,97-0,99$, which corresponds to the relationship between the parameters that is close to the functional one. Dependency graphs are rectified in double logarithmic coordinates and approximated by an equation of the form

$$
(n-1) I>I_{t r i p}>I_{s c},
$$

where $a=0,38-0,47$ and $b=0,64-0,71$. 


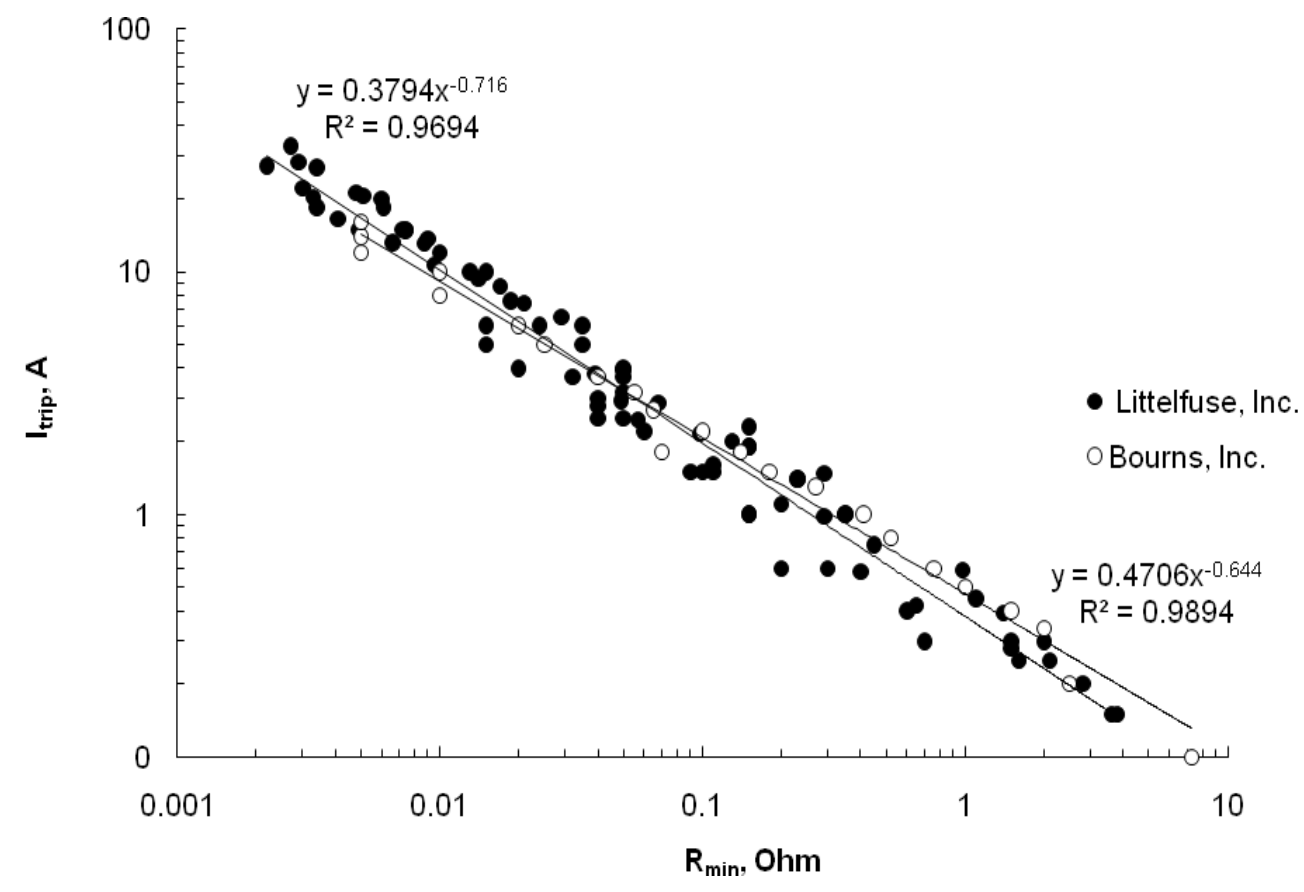

Fig. 5. Correlation between the resistance in the conducting state $\boldsymbol{R}_{\min }$ and the tripping current $\boldsymbol{I}_{\text {trip }}$ for serial low-power RF's from various manufacturers.

This relationship allows us to estimate the prospects of applying RF's produced nowadays to limit current overloads in photovoltaic systems. In particular, this implies that the chosen value $R_{\min }$ limits the range of tripping currents from below. For example, for $R_{\min }$ $<0,1 \mathrm{Ohm}$ there are only RF's with tripping currents $I_{\text {trip }}>2 \mathrm{~A}$. In this case, the more $R_{\text {min }}$, the less tripping currents can be.

Proceeding from this, we can conclude that the modern base of commercial RF's allows providing protection against current overloads in parallel connections of photovoltaic modules. In the simplest case, such modules are serial connections of several dozen PVC's [24] and, thus, have a sufficiently high series effective electrical resistance $r_{s}$. For example, photovoltaic modules developed on the basis of silicon wafers KEF-4.5 have an effective series resistance of up to $r_{s}=3 \mathrm{Ohms}$ and a short circuit current $I_{s c}=2 \mathrm{~A}$ [25]. In accordance with the dependence of Fig. 5, to implement protection against current overloads in the unit (parallel connection) of such photovoltaic modules, we can find suitable RF's satisfying conditions (1) and (2) (for example, FRX375-60F [26]).

At the same time, for parallel connection of typical silicon PVC's with $r_{s}=1 \mathrm{Ohm}$ and the short circuit current $I_{s c}$ magnitude of about 0,05 A [27], as evidenced by the data in Fig. 5, it is impossible to find a suitable RF.

It should be noted that RF parameters $I_{\text {trip }}$ and $R_{\min }$ determine the amount of heat required for the transition of the crystalline structure of the polymer matrix into amorphous one. Currently applied nanocomposites for RF's use polyethylene with a melting point of $125^{\circ} \mathrm{C}$ as the matrix phase. Replacing polyethylene with a material with a lower melting point should lead to a decrease in the power required to achieve it, and thus to create an RF with smaller $I_{\text {trip }}$ and $R_{\min }$. 
It seems that solving such a technological problem in the future may also lead to the implementation of protection against current overloads in solar arrays at the level of photovoltaic cells.

\section{Conclusions}

A general scheme for the use of self-repairing PolySwitch fuses for current limiting in parallel connections of photovoltaic components of solar arrays is presented and analyzed. The requirements for fuse parameters are formulated.

The presence of self-resetting fuses in the electrical circuit should not affect the normal operation of the photovoltaic modules, and the response current of the fuses must be greater than the short-circuit current of the photovoltaic cell and less than the parallel current of the photovoltaic cells module in the operating mode. The resistance of the fuses must be significantly less than the resistance of the protected elements.

Replacing polyethylene with a material with a lower melting point should lead to a decrease in the power required to switch them, and thus to the creation of resettable fuses with a lower response current and a lower minimum initial resistance.

\section{References}

1. Köntges, M. Review of failures of photovoltaic modules. IEA PVPS Task 13 / M. Köntges, S. Kurtz, C. Packard, U. Jahn, K.A. Berger, K. Kato, T. Friesen, H. Liu, M. VanIseghem. - 2014. - $132 \mathrm{p}$.

2. United Solar Technologies - Solar Modules and Arrays [Electronic resource]. Access mode: $\mathrm{http} / / /$ ust.su/solar/media/section-inner17.

3. Tonkoshkur, A.S. Schemotechnical technologies for reliability of solar arrays / A.S. Tonkoshkur, L.V. Nakashidze., S.F. Lyagushyn // Systemni Tekhnolohiyi. Rehional'nyi mizhvuzivs'kyi zbirnyk naukovykh prats'. - Issue 4'(117) - Dnipro, 2018. - P. 95 - 107.

4. Nadiradze, A.B. Issledovaniye degradatsii kharakteristik planarnykh solnechnykh batarey pod deystviyem tviordykh chastits yestestvennogo $i$ iskusstvennogo proiskhozhdeniya / A.B. Nadiradze. - Avtoref. diss. ... kand. tekhn. nauk. - M.: MAI, 1994. $-26 \mathrm{p}$.

5. Novikov, L.S. Shuntirovaniye elementov solnechnykh batarey pri odinochnykh udarakh tviordykh chastits / L.S. Novikov, A.B. Nadiradze, C.A. Bedniakov, A.V. Gavriushin // Trudy MAI. - 2000. - No. 1 .

6. Kim, K.A. Photovoltaic hot spot analysis for cells with various reverse-bias characteristics through electrical and thermal simulation / K.A. Kim, P.T. Krein // Proc. IEEE Workshop Control Modeling Power Electron., June 2013. - P. 1 - 8.

7. Kim, K.A. Reexamination of photovoltaic hot spotting to show inadequacy of the bypass diode / K.A. Kim, P.T. Krein // IEEE J. Photovoltaics. - No. 5 (5). - P. 1435 - 1441.

8. Acciari, G. Higher PV module efficiency by a novel CBS bypass / G. Acciari, D. Graci, A.L. Scala // IEEE Trans. Power Electron. - May 2011. - Vol. 26, No. 5. - P. 1333 - 1336.

9. d'Alessandro V. A simple bipolar transistor-based bypass approach for photovoltaic modules / V. d'Alessandro, P. Guerriero, S. Daliento // IEEE J. Photovoltaics. - Jan. 2014. Vol. 4, No. 1. - P. $405-413$.

10. Sánchez Pacheco F.J. Photovoltaic systems distributed monitoring for performance optimization / F.J. Sánchez Pacheco. - Doct. Thesis. - Universidad de Málaga (RIUMA), Málaga, España, 2015.

11. Di Napoli, F. Single panel voltage zeroing system for safe access on PV plants / F. Di Napoli, G. Guerriero, V. d'Alessandro, S. Daliento // IEEE J. Photovoltaics. - 2015. No.5 (5). - P. 1428 - 1434. 
12. Tonkoshkur, A.S. Primeneniye samovosstanavlivayushchikhsia elementov dlia elektricheskoy zashchity solnechnykh batarey / A.S. Tonkoshkur, A.V. Ivanchenko, L.V. Nakashidze, S.V. Mazurik // Tekhnologiya i konstruirovaniye v elektronnoy apparature. 2018. - No. 1. - P. $43-49$.

13. Gavrikov, V. Samovosstanavlivayushchiyesia PTC-predokhraniteli dlia zashchity ot tokovykh peregruzok / V. Gavrikov // Novosti Elektroniki. - 2014. - No. 12. - P. 11 - 15.

14. Pat. 6608470 USA. Overcharge protection device and methods for lithium based rechargeable batteries / J.W. Oglesbee, A.G. Burns. - 19.08.03.

15. Protecting rechargeable $\mathrm{Li}$-ion and $\mathrm{Li}$-polymer batteries [Electronic resource]. Littelfuse, $\quad$ Inc., $2017 . \quad-\quad$ Access mode: http://www.littelfuse.com/ /media/electronics/application_notes/littelfuse_protecting _rechargeable_li_ion_and_li_polymer_batteries_in_consumer_portable_electronics_applicati on_note.pdf.pdf

16. Levshov, A.V. O matematicheskom modelirovanii fotoelectricheskih moduley / A.V. Levshov, A.Yu. Fiodorov // Naukovi pratsi DonNTU. Seriya: «Elektrotekhnika i enerhetyka». - 2013. - No. 1(14). - P. 153 - 158.

17. Raushenbah, G. Spravochnik po proektirovaniyu solnechnyh batarey / G. Raushenbah. - M.: Energoatomizdat, 1983. - 360 p.

18. Lorenzo, E. Solar Electricity Engineering of Photovoltaic Systems / E. Lorenzo// Artes Graficas Gala. - Spain, 1994.

19. Tonkoshkur, O.S. Fizychni osnovy elektrychnoho kontroliu neodnoridnyh system. Navchalnyi posibnyk / O.S. Tonkoshkur, V.U. Ignatkin. - Dniprodzerzhinsk: DDTU, 2010. $290 \mathrm{p}$.

20. Glot, O.B. Oksydni keramichni varystory / O.B. Glot, O.I. Ivon, O.S. Tonkoshkur, I.M. Chernenko. - Dnipropetrovsk: DDU, 1998. - 140 p.

21. Tonkoshkur, O.S. Komponentna baza REA / O.S. Tonkoshkur, O.N. Trystan, O.M. S'yanov. - Dniprodzerzhinsk: DDTU, 2004. - 240 p.

22. https://www.bourns.com/docs/Product-Datasheets/mfr.pdf

23. https://m.littelfuse.com/ /media/electronics/datasheets/resettable_ptcs/littelfuse_ptc_ radial_leaded_catalog_datasheet.pdf.pdf

$\overline{24}$. Chen, K. H. Study of crystalline silicon solar cells with integrated bypass diodes / K. H. Chen, D. M. Chen, Y. B. Zhu Y B, et al. // Sci. China Tech. Sci. - 2012. - Vol. 55, No. 3. - P. $594-599$.

25. Al-Oran, B.F. Issledovaniye i razrabotka kremniyevyh solnechnyh elementov dlia fotoelektricheskih stantsiy i batarey nazemnogo primeneniya / Bilal Fuad Al-Oran. - Avtoref. dis. ... kand. tehn. nauk. - Tashkent: Institut energetiki i avtomatiki Akademii nauk Respubliki Uzbekistan, 1995.

26. http://www.fuzetec.com/products_2.php?bgid=1\&gid=31

27. Koval, O.S. Opredeleniye parametrov solnechnogo iz yego svetovoy volt-ampernoy harakteristiki / O.S. Koval, M.S. Tivanov // Veastnik BGU. - 2012. - Ser. 1, No. 2. - P. 39 44. 